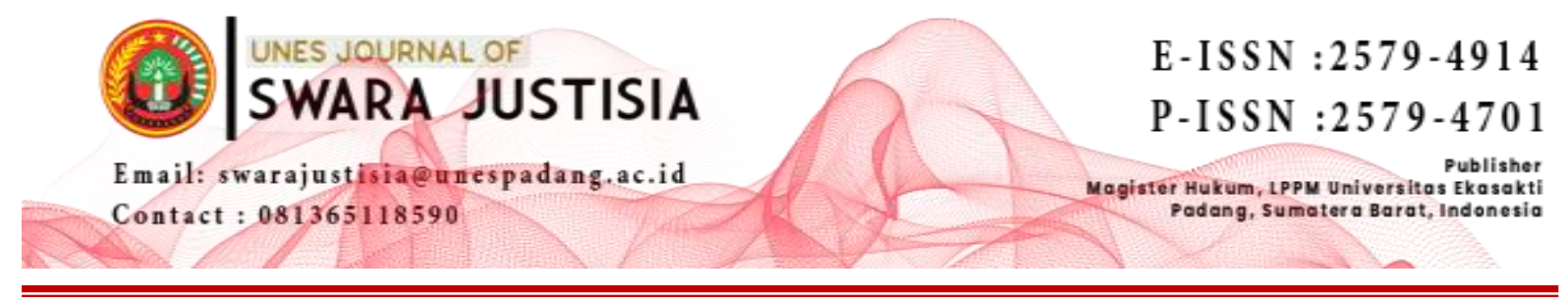

\title{
PENEGAKAN HUKUM TERHADAP PENGEMUDI TRUCK TRADO OVERLOADYANG MENGAKIBATKANBANYAKNYA KORBAN KECELAKAAN LALU LINTAS (Studi Pada Satuan Lalu Lintas Kepolisian Resor Padang Pariaman)
}

\author{
${ }^{1)}$ Randhi Permana, ${ }^{2)}$ Fahmiron \\ 1) Program Magister Ilmu Hukum,Universitas Ekasakti, Padang \\ Email: randhipermana89@gmail.com \\ 2) Program Magister Ilmu Hukum,Universitas Ekasakti, Padang \\ Email: fahmiron@gmail.com
}

\begin{abstract}
Law Number 22 of 2009 concerning Road Traffic and Transportation is intended to realize security and safety and order in traffic should be able to bring about important changes in the way of life of road traffic in Indonesia. However, in reality, based on empirical facts, it shows that legal compliance in society in road traffic is decreasing. Many road users do not comply with traffic regulations, Lack of supervision and law enforcement, especially against traffic violations involving overloaded goods by trucks that are affiliated with the needs of traffic activities, especially on Padang Pariaman cross path that connects the road between West Sumatra Province and Riau Province. The bad impact that arises is the potential for traffic accidents to occur which can be fatal for other motorists considering the dimensions and loads of the vehicle are quite wide, especially because technically the truck is not in accordance with the transport procedure. Based on the discussion and analysis, it can be concluded that: First, Law enforcement against Trado Overload Truck Drivers which results in many victims of traffic accidents in the jurisdiction of the Padang Pariaman Police, as determined in accordance with the procedure, starting with a report to the picket. then help the victim secure the crime scene, secure the suspect then enter into the investigation of witness examination, the suspect confiscate evidence then the file is sent to the prosecutor. Second, the obstacles in law enforcement against Trado Overload Truck Drivers which result in the large number of victims of traffic accidents in the jurisdiction of the Padang Pariaman Police, namely internal constraints in the form of limited funds, limited facilities and infrastructure. the limited number of traffic police personnel compared to the legal area which is quite large and external constraints in the form of not being cultured by the community to provide information as witnesses to what is witnessed for the purposes of investigation because people are lazy to take the time and leave their routine work.
\end{abstract}

Keywords: Law Enforcement, Accident, Victim 


\begin{abstract}
ABSTRAK
Undang-Undang Nomor 22 Tahun 2009 tentang Lalu Lintas dan Angkutan Jalan dimaksudkan untuk terwujudnya keamanan dan keselamatan serta ketertiban dalam berlalu lintas seharusnya dapat membawa perubahan penting dalam tata kehidupan berlalu lintas jalan raya di Indonesia. Namun pada kenyataannya berdasarkan fakta Empiris menunjukan bahwa ketaatan hukum dalam masyarakat dalam berlalu lintas di jalan raya semakin berkurang. Para penguna jalan banyak yang tidak mematuhi peraturan lalu lintas, Kurangnya pengawasan dan penegakan hukum, khususnya terhadap tindak pidana pelanggaran lalu lintas yang menyangkut muatan kelebihan beban (over load) oleh kendaraan truk-truk barang yang beraviliasi terhadap kebutuhan-kebutuhan kegiatan berlalu lintas khususnya pada jalur lintas padang pariaman yang menghubungkan jalan antar Provinsi Sumatera Barat dengan Provinsi Riau. Dampak buruk yang timbul adalah berpotensi terjadi kecelakaan lalu lintas yang berakibat fatal bagi pengendara lainnya mengingat dimensi dan beban kendaraan yang cukup lebar apalagi secara teknis kendaraan truck tidak sesuai dengan prosedur pengangkutan. Berdasarkan pembahasan dan analisis dapat disimpulkan bahwa:PertamaPenegakan hukum Terhadap Pengemudi Truck Trado Overload Yang Mengakibatkan banyaknya korban kecelakaan lalu lintas di wilayah hukum Polres Padang Pariaman seperti mana yang ditentukan sesuai dengan prosedur dimulai dengan adanya laporan kepada piket. kemudian menolong korban mengamankan TKP mengamankan tersangka kemudian masuk terhadap penyidikan pemeriksaan saksi, tersangka penyitaan barang bukti kemudian pemberkasan dikirimkan ke JPU. Kedua Kendala-kendala dalam penegakan hukum Terhadap Pengemudi Truck Trado Overload Yang Mengakibatkan banyaknya korban kecelakaan lalu lintas pada wilayah hukum Polres Padang Pariaman yaitu kendala internal berupa keterbatasan dana, keterbatasan sarana dan prasarana. keterbatasan jumlah personil polisi lalu lintas dibandingkan wilayah hukum yang cukup besar dan kendala eksternal berupa belum membudayanya masyarakat untuk memberikan keterangan sebagai saksi terhadap apa yang di saksikanuntuk kepentingan penyidikan dikarenakan masyarkat malas meluangkan waktu dan meninggalkan perkerjaan rutinitas nya.
\end{abstract}

Kata Kunci: Penegakan Hukum, Kecelakaan, Korban

\title{
PENDAHULUAN
}

Lalu Lintas dan Angkutan Jalan mempunyai peran strategis dalam mendukung pembangunan dan integrasi nasional sebagai bagian dari upaya memajukan kesejahteraan umum sebagaimana diamanatkan oleh Undang-Undang Dasar Negara Republik Indonesia tahun 1945, Lalu Lintas dan Angkutan Jalan sebagai bagian dari sistem transportasi nasional harus dikembangkan potensi dan perannya untuk mewujudkan keamanan, keselamatan, ketertiban, dan kelancaran berlalu lintas dan angkutan jalan dalam rangka mendukung pembangunan ekonomi dan pengembangan wilayah, serta perkembangan lingkungan strategis nasional dan internasional menuntut penyelenggaraan lalu lintas dan angkutan jalan yang sesuai dengan perkembangan ilmu pengetahuan dan teknologi, otonomi daerah, serta akuntabilitas penyelenggaraan negara. ${ }^{1}$

Pasal 310 Undang-undang Nomor 22 Tahun 2009, disebutkan bahwa apabila kealpaan atau kelalaian pengemudi itu mengakibatkan orang lain terluka atau meninggal dunia ancaman pidananya sebagaimana yang diatur dalam Pasal tersebut diatas. Hal ini

\footnotetext{
${ }^{1}$ Konsideran menimbang huruf a, b dan c Undang-Undang Nomor 22 tahun 2009 tentang Lalu Lintas dan Angkutan Jalan.
} 
mencerminkan kedudukan norma hukum yang penuh otonomi, jadi bukan semi otonomi itu. $^{2}$ Meski Undang-Undang Lalu lintas dan angkutan jalan telah diterapkan sampai dengan sekarang tapi tidak dapat dipungkiri bahwa tingkat kecelakaan masih tetap terjadi. Di dalam kehidupan sehari-hari polisi pasti akan menghadapi bermacam-macam manusia dengan latar belakang maupun pengalaman masing-masing. ${ }^{3}$

Dengan banyaknya kasus kecelakaan di jalan raya setidaknya itu bisa menggambarkan cerminan masyarakatnya betapa minimnya kesadaran hukum bagi pengendara sepeda motor. Karena masih banyak orang-orang mengemudi tidak tertib dan taat pada rambu-rambu lalu lintas. Meningkatnya jumlah korban dalam suatu kecelakaan merupakan suatu hal yang tidak diinginkan oleh berbagai pihak, mengingat betapa sangat berharganya nyawa seseorang yang sulit diukur dengan sejumlah uang satuan saja.

Orang yang mengakibatkan kecelakaan tersebut harus mempertanggung jawabkan perbuatannya dengan harapan pelaku dapat jera dan lebih berhati hati. Berhati hatipun tidaklah cukup untuk menghindari kecelakaan, faktor kondisi sangatlah di utamakan dalam mengendarai kendaraan dan juga kesadaran hukum berlalu lintas harus dipatuhi sebagaimana mestinya.

Dengan dikeluarkannya Kitab Undang-Undang Hukum Acara Pidana (UU No.8/1981) sudah selayaknya kita semua menyambut gembira kehadiran Undang-Undang tersebut ditengah-tengah kita, oleh karena undang-undang tersebut diharapkan akan membawa gagasan baru dengan napas humanisme dan nilai keadilan yang didambakan oleh semua pihak dalam masyarakat kita. Nilai keadilan yang sesuai dengan Pancasila sebagai falsafah bangsa Indonesia haruslah merupakan nilai yang dapat memelihara dan mempertahankan keseimbangan, keserasian dan keselarasan antara kepentingan individu di satu pihak dan kepentingan masyarakat dipihak lain. ${ }^{4}$

Sedangkan ketentuan pidana terdapat pada Pasal 310 Undang-Undang Nomor 22 Tahun 2009 Tentang Lalu Lintas dan Angkutan Jalan (LLAJ) yang menyatakan :

Pasal 310 ayat 4 tersebut berbunyi, "Setiap orang yang mengemudikan kendaraan bermotor yang karena kelalaiannya mengakibatkan kecelakaan lalu lintas dengan korban orang lain meninggal dunia, dipidana dengan pidana penjara paling lama 6 (enam) tahun dan/atau denda paling banyak Rp. 12.000.000,00 (dua belas juta rupiah.

Menurut Pasal 1angka 24 Undang-undang nomor. 22 Tahun 2009 tentang Lalu Lintas dan Angkutan Jalan, kecelakaan lalu lintas adalah suatu peristiwa di Jalan yang tidak diduga dan tidak disengaja melibatkan Kendaraan dengan atau tanpa Pengguna Jalan lain yang mengakibatkan korban manusia dan/atau kerugian harta benda. Salah satu upaya untuk menanggulangi tunggakan perkara seperti yang dikemukakandalam buku H.P Panggabean adalah dengan memperdayakan penyelesaian alternatif di luar pengadilan melalui "upaya damai" atau alternatif dispute resolution (ADR).

\footnotetext{
${ }^{2}$ Harie Tuesang, Upaya Penegakan Hukum Dalam Era Reformasi,. Penerbit Restu Angung, Jakarta, 2009, hlm. 14

${ }^{3}$ Soeriono Spekanto, Faktor-Faktor yang Mempengaruhi Penegakan Hukum, PT RajaGarfindo Persada, Jakarta, 2012, hal 48

4 Romli Atmassasmita, Sistem Peradilan Pidana Komtemporer, Kencana Prenada Media Group, Jakarta, 2010, hlm. 67.
} 
Menurut Barda Nawawi Arief, "Memperluas berlakunya Pasal 82 Kitab UndangUndang Hukum Pidana (yaitu mengenai "afkoop" atau pembayaran denda damai sebagai alasan penghapus penuntutan untuk delik "pelanggaran")terhadap semua tindak pidana termasuk "kejahantan" walaupun dapat saja dibatasi berlakunya berdasarkan pembatasn ancaman maksimal pidananya".

Sanksi hukum pidana mempunyai pengaruh preventif (pencegahan) terhadap terjadinya pelanggaran-pelanggaran norma hukum. Pengaruh ini tidak hanya ada apabila sanksi pidana itu benar-benar diterapkan terhadap pelanggaran yang konkrit, akan tetapi sudah adasejak dicantumkan dalam peraturan perundang-undangan (theorie des psychischen zwanges ajaran psychis). Sebagai alat kontrol sosial (social control), fungsi hukum pidana adalah subsidier, artinya hukum pidana hendaknya baru diadakan apabila usaha-usaha lain kurang memadai. Hukum pidana merupakan hukum publik, artinya bahwa hubungan hukum diatur terletak pada kepentingan orang banyak (umum), yang biasanya diwakili oleh pemerintah. Sebagai hukum publik berarti sama dengan hukum tata negara maupun hukum administrasi negara. Disamping hukum publik, ada hukum privat (hukum perdata).Hukum perdata mengatur hubungan antara orang perorang.

Setiap kepentingan yang hendak dipersoalkan tergantung pada masing-masing individu. Hukum tata negara, hukum administrasi negara maupun perdata mempunyai sanksi sendiri-sendiri sebagai sarana untuk menanggulangi perbuatan melanggarnya. Untuk mencapai tujuan hukum, yaitu mewujudkan ketertiban dan kesejahteraan masyarakat, di samping jenis-jenis sanksi tersebut, biasanya digunakan pula sanksi pidana sebagai sarana terakhir (pamungkas). Sanksi pidana sebagai sarana terakhir ini disebut Ultimatum Remedium, yakni obat terakhir, artinya bahwa sanksi pidana hendaknya baru digunakan apabila sanksi atau upaya-upaya hukum yang lain sudah tidak mampu.

Kasus kecelakaan truk tangki bermuatan aspal cair dari Padang Panjang menuju Padang Pariaman sesampai di Air Mancur terjadilah rem blong kecelakaan tunggal truk tersebut menyerempet kepinggir jalan dan truk tidak bisa jalan jadi harus membutuhkan alat berat ketika alat berat sampai di tempat kejadian ternyata mobil truk ini tidak bisa jalan harus digendong pakai mobil gendong ketika itu SOP tidak dipakai oleh pihak mobil Trado yaitu SOP seharusnya barang yang digendong diukur dulu berapa beratnya berapa ukurannya, karna keadaan mendesak jalan macet situasi di air mancur jalan kecil dan jalan lintas Provinsi mengingat situasi jalan macet langsung truk dinaikkan diatas mobil gendong dan seharusnya isi truk tersebut harus disalin baru dinaikkan ke mobil Trado mengingat jalan macet panjang dan hari hujan langsung dianaikkan kemobil Trado, setelah dinaikan truk tersebut kemobil gendong dan sudah jalan 1 kilo dari tempat evakuasi dipertikungan jalan masih ramai dan pas dipembelokan isi aspal tersebut jatuh dan truk diatas mobil Trado tersebut jatuh dan mengenail mobil sebelah kanan dari mobil gendong tersebut yang berlawanan arah dan disebelah mobil tersebut ada mobil karimun 4 orang meninggal 2 orang selamat dan kena cairan aspal air karna ketidak hati-hatian dari pihak mobil trado dan tidak menjalan prosedur yang ada.

\section{METODE PENELITIAN}

Dalam penelitian ini spesifikasi penelitian yang di gunakan bersifat Deskriptif Analitis yaitu berusaha menggambarkan, menelaah lebih baik mengenai permasalahan yang akan 
diteliti, untuk kemudian menyusun dan menganalisa permasalahan tersebut. Metode pendekatan utama yang digunakan dalam penelitian ini adalah pendekatan yuridis normatif yaitu penelitian yang menekankan pada aspek-aspek hukum, dengan cara mempelajari bahan-bahan hukum primer dan hukum sekunder yang nantinya dijadikan pedoman dalam memahami dan menganalisis permasalahan yang dibahas, sedangkan sebagai pendukung pendekatan utama digunakan pendekatan yuridis empiris.

\section{PEMBAHASAN}

\section{A. Penegakan Hukum Terhadap Pengemudi Truk Trado Overload Yang Mengakibatkan Banyaknya Korban Kecelakaan Lalu Lintas}

Pada dasarnya program kegiatan Penegakan Hukum bukan berorientasi mencari kesalahan dari pengguna jalan tetapi lebih berorientasi pada perlindungan, pengayoman dan pelayanan pengguna jalan yang melanggar itu sendiri (Penindakan pelanggaran Helm, Sabuk pengaman dan kelengkapan kendaraan bermotor), Pengguna jalan lainnya (Penindakan pelanggaran SIM, Kecepatan, rambu, marka dan lainnya) serta kepentingan pengungkapan kasus pidana (Penindakan pelanggaran STNK, Nomor rangka, nomor mesin dan lainnya).

Pada penerapan ketentuan pidana dalam peristiwa kelalaian bagi pengemudi kendaraan yang mengakibatkan kecelakaan dapat ditemukan pasal-pasal yang menyangkut kelalaian. KUHP Pasal 359: Barang siapa karena kesalahannya (kelalaiannya) menyebabkan orang lain mati, diancam dengan pidana penjara paling lama lima tahun atau pidana kurungan paling lama satu tahun. Sedangkan Pasal 360 (1) Barangsiapa karena kesalahannya (kelalaiannya) menyebabkan orang lain mendapat luka-luka berat, diancam dengan pidana penjara paling lama lima tahun atau pidana kurungan paling lama satu tahun. (2) Barangsiapa karena kesalahannya (kelalaiannya) menyebabkan orang lain luka-luka sedemikian rupa sehingga timbul penyakit atau halangan menjalankan pekerjaan jabatan atau pencarian selama waktu tertentu, diancam dengan pidana penjara paling lama sembilan bulan atau pidana kurungan paling lama enam bulan atau pidana denda paling tinggi empat ribu lima ratus rupiah.

Proses penyelesaian hukum terhadap sopir truk karena kelalaian mengakibatkan orang lain meninggal dunia. Proses peradilan pidana adalah suatu rangkain acara peradilan mulai dari penindakan terhadap adanya tindak pidana (sumber tindakan) sampai pada lahirnya keputusan pengadilan yang mempunyai kekuatan hukum.

Dari beberapa penelitian dan pengkajian dilapangan factor korelatif yang dapat mempengaruhi stabilitas keamanan, keselamatan, ketertiban dan kelancaran lalulintas di jalan raya merupakan interaksi serta kombinasi dua atau lebih factor yang saling mempengaruhi situasi lalu lintas meliputi faktor manusia, faktor kendaraan, factor jalan, dan faktor lingkungan. ${ }^{5}$

Manusia sebagai pemakai jalan yaitu sebagai pejalan kaki dan pengendara kendaraan baik kendaraan bermotor maupun kendaraan tidak bermotor. Interaksi antara faktor Manusia, Kendaraan, Jalan dan Lingkungan sangat bergantung dari perilaku

${ }^{5}$ Hasil Wawancara dengan Kasat Lantas Polres Padang Pariaman, Iptu Indra Kusuma, hari senin, tanggal 02 November 2020. 
Manusia sebagai pengguna jalan menjadi hal yang paling dominan terhadap Kamseltibcar Lantas, hal ini sangat ditentukan oleh beberapa indikator yang membentuk sikap dan perilakunya di Jalan raya berupa: ${ }^{6}$

\section{Mental}

Mental dan perilaku yang membudaya dari pengguna jalan merupakan salah satu faktor utama yang sangat berpengaruh terhadap situasi lalu lintas. Etika, sopansantun, toleransi antar pengguna jalan, kematangan dalam pengendalian emosi serta kepedulian pengguna jalan di jalan raya akan menimbulkan sebuah interaksi yang dapat mewarnai situasi lalu lintas berupa hasil yang positif seperti terciptanya keamanan, keselamatan dan kelancaran lalu lintas maupun dampak negatif yang dapat menimbulkan kesemrawutan, kemacetan, pelanggaran dan kecelakaan lalu lintas, sehingga mentalitas pengguna Jalan merupakan suatu hal yang pondamental dalam mewujudkan situasi lalu lintas yang baik.

Mental dan perilaku pengguna jalan merupakan suatu cerminan budaya berlalu lintas, hal ini tidak dapat dibentuk secara instant oleh suatu lembaga tertentu, baik itu lembaga pendidikan maupun lembaga lainnya, tetapi terbentuk secara berkesinambungan mulai kehidupan sehari-hari dalam keluarga, lingkungan dan situasi lalu lintas yang kasat mata secara keseharian selalu terlihat oleh pengguna jalan sehingga membentuk kultur mentalitas berlalu lintas seseorang.

2. Pengetahuan

Dalam menciptakan dan memelihara Keamanan, Keselamatan, Ketertiban serta Kelancaran Lalu lintas, telah dilakukan pengaturan yang disesuaikan dengan perkembangan situasi lalu lintas yang ada dengan mempertimbangkan perkembangan teknologi di bidang transportasi baik yang berhubungan dengan kendaraan, sarana dan prasarana jalan serta dampak lingkungan lainnya dalam bentuk suatu aturan yang tegas dan jelas serta telah melalui roses sosialisai secara

bertahap sehingga dapat dijadikan pedoman dalam berinteraksi di jalan raya. Setiap Pengguna Jalan wajib memahami setiap aturan yang telah dibakukan secara formal baik dalam bentuk Undang-Undang, Perpu, Peraturan Pemerintah, Perda dan aturan lainnya sehingga terdapat satu persepsi dalam pola tindak dan pola pikir dalam berinteraksi di jalan raya. Perbedaan tingkat pengetahuan dan atau pemahaman terhadap aturan yang berlaku mengakibatkan suatu kesenjangan yang berpotensi memunculkan permasalahan dalam berlalu lintas, baik antar pengguna jalan itu sendiri maupun antara pengguna jalan dengan aparat yang bertugas untuk melaksanakan penegakkan hukum di jalan raya. Selain pemahaman terhadap pengetahuan tentang peraturan perundangundangan yang berlaku, pengetahuan tentang karakteristik kendaraan merupakan suatu hal yang tidak dapat diabaikan, setiap kendaraan memiliki karakteristik yang berbeda dalam penanganannya, pengetahuan terhadap karakteristik kendaraan sangat berpengaruh terhadap operasional kendaraan di jalan raya yang secara otomatis akan berpengaruh pula terhadap situasi lalu lintas jalan

${ }^{6}$ Hasil Wawancara dengan Kasat Lantas Polres Padang Pariaman, Iptu Indra Kusuma, hari senin, tanggal 02 November 2020. 
raya, pengetahuan tentang karakteristik kendaraan bisa didapat dengan mempelajari buku manual kendaraan tersebut serta dengan mempelajari karakter kendaraan secara langsung (fisik).

3. Keterampilan

Kemampuan dalam mengendalikan (Mengendarai/Mengemudi) Kendaraan baik kendaraan bermotor maupun kendaraan tidak bermotor di jalan raya akan berpengaruh besar terhadap situasi lalu lintas, keterampilan mengendalikan kendaraan merupakan suatu keharusan yang mutlak demi keamanan, keselamatan, ketertiban dan kelancaraan lalu lintas baik bagi pengemudi/pengendara kendaraan tersebut maupun pengguna jalan lainnya. Lisensi terhadap kemampuan dalam mengendalikan kendaraan di wujudkan secara formal melalui Surat Izin Mengemudi yang di keluarkan oleh SATPAS Polri sesuai dengan peruntukan kendaraan bermotor yang dikemudikan/dikendarai oleh pengguna jalan sesuai dengan Peraturan Pemerintah Nomor 44 tahun 1993 tentang Kendaraan dan Pengemudi Bab VII tentang Pengemudi. Keterampilan mengendalikan (Mengendarai/Mengemudi) kendaraan baik kendaraan bermotor maupun kendaraan tidak bermotor diperoleh melalui serangkaian pelatihan sebelum mengajukan lisensi keterampilannya (SIM), secara formal khusus untuk kendaraan bermotor setiap pemohon SIM diwajibkan telah memiliki ketrampilan mengemudikan kendaraan bermotor yang dapat diperoleh baik melalui lembaga pendidikan dan pelatihan mengemudi maupun tidak melalui lembaga pendidikan dan pelatihan mengemudi yang berarti pemohon telah melalui proses pelatihan keterampilan sebelum dilanjutkan proses pengujian keterampilannya untuk mendapatkan SIM.

Seiring dengan peningkatan profesionalisme kepolisian, tuntutan ke arah perbaikan kinerja dan citra kepolisian sebagai pelayanan masyarakat telah menjadi agenda reformasi kepolisian. Daya kritis masyarakat sipil terhadap kinerja dan citra kepolisian adalah cerminan kuatnya aspirasi dan tuntutan atas hak-hak masyarakat.

Penegakan hukum pengemudi Truck Trado Overload megakibatkan kecelakaan lalu lintas berjalan seperti mana yang ditentukan sesuai dengan prosedur dimulai dengan adanya laporan kepada piket kemudian menolong korban mengamankan tempat kejadian perkara mengamankan tersangka kemudian masuk terhadap penyidikan pemerikasaan saksi dan tersangka penyitaan barang bukti kemudian pemberkasan dikirim ke Jaksa Penuntut Umum. ${ }^{7}$

Kepolisian Resor Padang Pariaman merupakan instansi yang petugas dan bertanggung jawab dalam pengamanan dan perlindungan bagi setiap warga masyarakat di wilayah hukumnya.Sesuai dengan fungsi dan tugasnya masing-masing, setiap fungsi juga mempunyai tanggung jawab yang berbeda. Dalam penanganan berbagai hal tentang perlalulintasan, baik administrasi lalu lintas, pelayanan Surat Izin Mengemudi (SIM), Surat Tanda Nomor Kendaraan (STNK), Buku Pemilik Kendaraan Bermotor (BPKB), informasi rambu dan marka, kecelakaan dan keramaian di jalan raya merupakan tanggung jawab dari Satuan Lalu Lintas (Satlantas) Kepolisian Resor Padang Pariaman.

${ }^{7}$ Hasil Wawancara dengan Kanit Laka Polres Padang Pariaman, Ipda Rudi Chandra, hari Selasa, tanggal 03 November 2020. 
Kecepatan petugas dalam mengenali dan memenuhi setiap kebutuhan pengguna layanannya merupakan sebuah tantangan tersendiri.Kemampuan petugas dalam memberikan pelayanan merupakan suatu faktor yang mempengaruhi kecepatan petugas dalam memberikan respon kepada pengguna layanannya.Kemampuan petugas kepolisian dalam menangani kecelakaan lalu lintas merupakan suatu hal yang mendasar dalam setiap merespon kebutuhan pengguna layanan.Kemampuan yang baik dan sesuai dengan kebutuhan dapat menunjukkan keprofesionalan petugas dalam melakukan penanganan sehingga dapat membangun citra positif dalam masyarakat.

\section{B. Kendala-kendala penegakan hukum Terhadap Pengemudi Truk Trado Overload Yang Mengakibatkan Banyaknya KorbanKecelakaan Lalu Lintas}

Dalam menangani kecelakaan lalu lintas yang terjadi di wilayah hukum Polres Padang Pariaman, Satuan Lalu Lintas (Satlantas) Polres Padang Pariaman pastilah tidak terlepas dari adanya kendala-kendala dalam pelaksanaannya.Kendala kendala tersebut bisa berasal dari dalam (internal) institusi maupun dari luar (eksternal) institusi Satuan lalu Lintas (Satlantas).

Kurangnya kesadaran hukum pada masyarakat dalam kaitannya dengan berlalu lintas sangat penting untuk mencegah terjadinya kecelakaan lalu lintas. Dengan demikian kesadaran hukum rnasyarakat baru akan tercipta apabila didukung oleh segenap elemen masyarakat, dapat dikemukakan di sini bahwa semakin besar kesadaran hukum masyarakat maupun seperti, maka akan semakin kecil kemungkinan masyarakst untuk bertingkah laku yang tidak sesuai dengan hukum.

Berdasarkan data kecelakaan lalu lintas yang terjadi di wilayah hukum Polres Padang Pariaman yang setiap tahunnya meningkat, menunjukkan bahwa kurangnya kesadaran hukum pada masyarakat dalam berlalu lintas menyebabkan angka kecelakaan selalu meningkat. Hal ini sejalan dengan apa yang disampaikan Tokoh Masyarakat Polres Padang Pariaman bahwa:

"Harus diakui bahwa masyarakat di Polres Padang Pariaman kesadaran hukumnya relatif masih rendah, apalagi mengenai kesadaran hukum dalam berlalu lintas, sungguh masih sangat memprihatinkan dan menimbulkan kekhawatiran seluruh elemen masyarakat, karena rata-ratas hampir setiap seminggu sekali selalu ada kecelakaan yang mengakibatkan korban tidak hanya luka berat dan ringan saja tetapi juga meninggal dunia".

Berdasarkan pembahasan dan analisis sebagaimana yang telah dipeparkan di atas, maka dapat disebutkan bahwa kendala-kendala yang dihadapi untuk mewujudkan profesionalisme Polisi Lalu Lintas dalam menanggulangi terjadinya kecelakaan lalu lintas di wilayah hukum Satuan lalu Lintas Polres Padang Pariaman ada 2 (dua), yaitu: pertama, kendala internal keterbatasan dana dan Keterbatasan sarana dan prasarana, kurangnya kemampuan Polisi Lalu Lintas, keterbatasan jumlah personil Polisi Lalalu lintas, kedua, kendala eksternal berupa belum terbudayanya untuk kecelakaan lalu lintas pada masyarakat dan kurangnya kesadaraan hukum dalam berlalu lintas.

Kendala-kendala dalam penegakkan hukum terhadap pengemudi truck Trado overload mengakibatkan kecelakaan lalu lintas masyarakat yang menberikan keterangan sebagai saksi kurang komperatif terhadap apa yang di saksikan maupun dilihat untuk 
kepentingan penyidikan dikarenakan masyarkat malas meluangkan waktu untuk memberikan keterangan terhadap pihak penyidik, tidak seimbang personil dibagian unit lakalantas dengan jumlah kecelakaan yang terjadi dikarenakan wilayah hukum terlalu besar dan sarana yang dipergunakan pada saat olah tempat kejadian perkara belum sesuai dengan apa yang telah ditentukan. ${ }^{8}$

\section{PENUTUP}

Penegakan hukum Terhadap Pengemudi Truck Trado Overload Mengakibatkan kecelakaan lalu lintas banyaknya korban di wilayah hukum Polres PadangPariaman. melihat Lalu Lintas dan Angkutan Jalan mempunyai peran strategis dalam mendukung pembangunan dan integrasi Nasional sebagai bagian dari upaya memajukan kesejahteraan umum. Salah satu tujuan nya yaitu mewujudkan pelayanan lalu lintas dan angkutan jalan yang aman, selamat, tertib, lancar untuk mendorong perekonomian nasional serta terwujudnya penegakan hukum dan kepastian hukum bagi masyarakat. dalam hal penegakan terhadap tersangka dijerat Pasal 310 ayat 4 UULAJ karena kelalaiannya mengakibatkan kecelakaan lalu lintas dengan korban meninggal dunia dari hasil proses penyidikan satlantas Polres Padang Pariaman kejadian ini disebabkan bukan karena teknis daripada kendaraan tetapi murni karena melanggar prosedur pengangkutan yang tidak sesuai ketentuan sehingga terjadi ketidak mampuan dari truck trado untuk menahan beban sehingga memang sangat berpotensi terhadap muatan yang di bawah rebah ke kanan karena kondisi jalan menanjak dan menikung.

Kendala-kendala penegakan hukum Terhadap Pengemudi Truck Trado Overload Mengakibatkan kecelakaan lalu lintas banyaknya korban pada wilayah hukum Polres Padang Pariaman beberapa kendala berupa dari segi internal yaitu terbatas nya peralatan yang mendukung dalam hal kegiatan olah TKP di lapangan sangat mempengaruhi terhadap proses evakuasi korban maupun kendaraan Dari segi ekternal yaitu masyarakat tidak komperatif untuk memberikan keterangan tentang apa yang dia saksikan maupun dia lihat untuk kepentingan penyidikan dikarenakan masyarakat malas untuk meluangkan waktu.

\section{REFERENSI}

Harie Tuesang, Upaya Penegakan Hukum Dalam Era Reformasi,. Penerbit Restu Angung, Jakarta, 2009

Romli Atmassasmita, Sistem Peradilan Pidana Komtemporer, Kencana Prenada Media Group, Jakarta, 2010

Soeriono Spekanto, Faktor-Faktor yang Mempengaruhi Penegakan Hukum, PT RajaGarfindo Persada, Jakarta, 2012

Undang-Undang Dasar Negara Republik Indonesia Tahun 1945

Undang-Undang Nomor 22 Tahun 2009 Tentang Lalu Lintas dan Angkutan Jalan

${ }^{8}$ Hasil Wawancara dengan Kanit Laka Polres Padang Pariaman, Ipda Rudi Chandra, hari Selasa, tanggal 03 November 2020 